\title{
Ethnicity and social relations in Indonesian television production houses
}

\author{
Maria Myutel
}

In Indonesia the industry producing the most popular commercial TV programmes, known as sinetron, is largely dominated by Indonesians of Indian (Sindhi) origin. This article examines social relations within the sinetron production houses and argues that between the 1990s and the early 2010s the distribution of symbolic and material capital depended on ethnicity, as it was imagined and constituted by two rather different cultural frameworks and historical experiences. One is based on the occupational distinction, rooted in the South Asian caste system, while the other can be traced back to ethnic classifications in colonial Indonesia.

For millions of people in Indonesia, as well as across the globe, television is a big part of life. For some television is their life. This is especially true for those who are involved in producing content for private free-to-air national television stations in Indonesia. The demand for entertainment programmes causes the industry to operate in $24 / 7$ mode, producing up to 120 hours of entertainment daily. ${ }^{1}$ Industry practitioners spend their lives in the meeting rooms of production house offices and on sets. Long hours of intellectual, creative, physical and emotional labour are compressed into short episodes of endless television shows. These hours also shape a behindthe-scenes culture, the mysterious and fashionable world of creative industries.

This article examines the role of ethnicity in the production culture of Indonesian television production houses (PHs) since their inception in the 1990s up to the early 2010s. At that time the biggest PHs supplying private Indonesian TV channels with

Maria Myutel is a $\mathrm{PhD}$ candidate at the School of Culture, History and Language (CHL), College of Asia and the Pacific, the Australian National University, Canberra. Correspondence in connection with this article should be addressed to: maria.myutel@anu.edu.au. The author would like to thank Ariel Heryanto, Craig Reynolds and two anonymous JSEAS reviewers for their critical comments and suggestions on previous drafts of this article. The author would also like to express gratitude to her respondents for sharing their thoughts about the complex world of television drama production. Interviewee names are pseudonyms with the exception of the $\mathrm{PH}$ owners. Quotes from the English language interviews are verbatim; all translations of the interviews in Indonesian are mine.

1 This is a very rough estimate based on the following data: 11 channels with approximately half of the air time (8 to 10 hours) allocated for entertainment programmes. According to Rachmah Ida, Imaging Muslim women in Indonesian Ramadan soap operas (Bangkok: Asian Muslim Action Network; Chiang Mai: Silkworm, 2010) sinetron commands up to 80 per cent of private television space. 
the most popular entertainment programmes, known in Indonesian as sinetron (sinema elektronik; any film produced on electronic media), ${ }^{2}$ were owned and run by several families of Hindu Sindhis, a tiny ethnocultural group that had permanently settled in Indonesia in the late 1940s after India's independence and the Partition in 1947. ${ }^{3}$ While most Indonesian Sindhis established themselves in their traditional textile and luxury goods trades, ${ }^{4}$ several families branched out, largely by chance, into the distribution and then the production of feature films. When commercial television was introduced in Indonesia in the late 1980s Indonesian Sindhis were the first to respond to the new market demand by establishing enterprises solely to produce sinetron. In fact, Sindhis are often credited with developing the whole commercial sinetron industry, which has continued to grow steadily since 1992, when the first show produced for commercial television was successfully aired on a private TV station (RCTI). Raam Punjabi, the most successful sinetron producer, followed by his nephew, Manoj Punjabi, another prosperous media mogul, have earned the title of Raja sinetron (lit., 'King of soap opera') and are repeatedly named by Forbes as being among Indonesia's richest persons.

Media production culture is shaped by its sociocultural context. ${ }^{5}$ Hierarchies and 'material practices' within the commercially driven film and television industries are not universal, but are deeply embedded in local culture and history. ${ }^{6}$ Meanwhile, social relations within a production studio can be seen as a microcosm of the larger society. In the United States, for instance, privilege and distinction in the industry are based on a division known in industry jargon as 'above/below-the-line', which in

2 Sinetron is often translated as soap opera, but it is an umbrella term for various TV genres (drama, legend, mystery, teenage drama, etc.) and formats (series, serials, mini-series and TV films). Budi Irawanto, 'Menertawakan kejelataan kita-kita: Transgresi batas-batas marginalitas dalam sinetron komedi Bajaj Bajuri [Laughing at our commonfolk: Transgressing the boundaries of marginality in the comic sinetron Bajaj Bajuri]', Jurnal Ilmu Komunikasi 3, 1 (2013): 51.

3 Throughout the article the terms 'Indonesian Sindhis', 'Indonesian Indians' or 'Indonesians of Indian descent' will be used interchangeably. With one exception, all Indonesian Indians who work in the sinetron production industry are Sindhis. In Indonesia there are also communities of Sikhs, Tamils, Marvaris, etc., but they are not in the industry. See A. Mani, 'Indians in rapidly transforming Indonesia', in Rising India and Indian communities in East Asia, ed. K. Kesavapany, A. Mani and P. Ramasamy (Singapore: Institute of Southeast Asian Studies [ISEAS], 2008), pp. 229-52.

4 See further Claude Markovits, The global world of Indian merchants, 1750-1947: Traders of Sind from Bukhara to Panama (Cambridge: Cambridge University Press, 2000); Mark-Anthony Falzon, Cosmopolitan connections: The Sindhi diaspora, 1860-2000 (Leiden: Brill, 2004).

5 See Anamik Saha, "Curry tales": The production of "race" and ethnicity in the cultural industries', Ethnicities 13, 6 (2013): 818-37; Vicki Mayer, Below the line: Producers and production studies in the new television economy (Durham: Duke University Press, 2011); Production studies: Cultural studies of media industries, ed. Vicki Mayer, Miranda J. Banks and John Thornton Caldwell (New York: Routledge, 2009); Barry Dornfeld, Producing public television, producing public culture (Princeton: Princeton University Press, 1998); Arlene Dávila, 'Culture in the ad world: Producing the Latin look', in Media worlds: Anthropology on new terrain, ed. Faye D. Ginsburg, Lila Abu-Lughod and Brian Larkin (Berkeley: University of California Press, 2002); Arlene Dávila, 'Talking back: Spanish media and U.S. Latinidad', in Latino/a popular culture, ed. Michelle Habell-Pallan and Mary Romero (New York: New York University Press, 2002); Tejaswini Ganti, Producing Bollywood: Inside the contemporary Hindi film industry (Durham: Duke University Press, 2012); Sherry B. Ortner, Not Hollywood: Independent film at the twilight of the American dream (Durham: Duke University Press, 2013).

6 Ganti, Producing Bollywood, p. 176. 
Sherry Ortner's words is 'clearly and visibly a class divide'. ${ }^{7}$ The below-the-line personnel are largely working class, while above-the-line staff represent socioeconomic elites. The class nature of this divide is obscured by the terminology used by observers, researchers and cultural industry professionals alike who term the labour of above-the-line workers as 'creative', in contrast to the 'technical' labour of below-the-line employees. Directors, producers, writers and actors are considered creative professionals, while editors, grips, make-up artists, etc., are seen as technical. ${ }^{8}$ Directors of photography (DOPs) are included in the above-the-line category by some and excluded by others. The varying use of the labels 'creative' and 'technical' imply, as John Caldwell suggests, that the distinction is rooted in the nature of the tasks media workers perform. ${ }^{9}$ Matt Stahl, however, argues that the 'line' and the different privileges associated with designations of 'creative' and 'technical' do not, in fact, 'flow naturally from differences in the tasks media workers do and the kinds of skills they bear', but are 'sedimented in the institutions, organizational forms and workers' self-understanding. ${ }^{10}$ Studies of media industries in the United States show that the material and symbolic benefits accorded to those below and above the line are the result of class struggles within the industry as well as a reflection of American society more generally. Upper classes find themselves in a privileged position while the working classes with their labour being 'the structuring absence' are often considerably disadvantaged. ${ }^{11}$

In India's Bollywood industry the major divide is drawn between the male stars and everyone else. ${ }^{12}$ The top male actors are accorded the best working conditions, in stark contrast with those of the rest of the cast and crew. More importantly, male stars have the power to initiate projects, which puts them at the top of the Bollywood hierarchy, higher than producers and directors. The importance of gender distinctions in Bollywood production culture corresponds with the prominence of gender distinctions in other spheres of Indian society.

I argue that in the case of the sinetron industry, social relations and the distribution of symbolic and material capital between the 1990s and the early 2010s depended on ethnicity, as it was imagined and constituted by two rather distinct cultural frameworks. The hierarchy inside PHs was shaped first by the Sindhis' views on social relations, according to which all people (Sindhi and non-Sindhi alike) are categorised

7 Ortner, Not Hollywood, p. 208. Throughout her work, Ortner uses class as the main analytical tool to help her explore changes in American society. She neither questions the validity of class as an analytical category nor redefines it. In general, she draws on 'an eclectic blend of different Marxist perspectives political economy, Frankfurt school, Birmingham/British cultural studies, and a kind of Marxist-inflected feminism.' Ibid., p. 11.

8 John T. Caldwell, Production culture: Industrial reflexivity and critical practice in film and television (Durham: Duke University Press, 2008), p. 38. There are also 'unregulated and nonsignatory sectors (assistants, agents, reps, clerical)'; ibid., p. 38.

9 The DOPs' ambiguous position in the production hierarchy is a good illustration of the constructive nature of the creative-technical divide.

10 Matt Stahl, 'Privilege and distinction in production worlds: Copyright, collective bargaining, and working conditions in media making', in Mayer et al., Production studies, pp. 54-5.

11 Mayer, Below the line.

12 Ganti, Producing Bollywood, p. 208. Gender plays a role in American media production as well, but is not seen as the prime aspect structuring social relations. See Ortner, 'Film feminism', Not Hollywood, chap. 6. 
based on their occupation. And second, the hierarchy was defined by a division into 'locals' and 'foreigners' (the latter including locals of foreign ethnicity along with those of foreign nationality), two major categories that Indonesians have continued to use for social identification since the Dutch colonial rulers introduced ethnicity as a classificatory grid for censuses. ${ }^{13}$

Ethnicity has remained a key socioeconomic and political factor in Indonesia. It was and still is often used as a marker of state- and self-identification, as a tool for political mobilisation, and as grounds for claiming state resources. Although in the 2000s the importance of ethnicity in political life decreased, ethnic imagery continues to play a vital role in public life. ${ }^{14}$ The politics of ethnicity in contemporary Indonesia is a developed field of research, which has attracted the attention of scholars from various disciplines. ${ }^{15}$ The Indonesians of Chinese descent have remained the main focus of such research, however. ${ }^{16}$ The exceptional scale of policies aimed at 'othering' Indonesians of Chinese heritage certainly justifies such profound academic interest. At the same time, not considering other significant ethnic groups, such as those of Indian, Dutch or Arab descent, has the potential to simplify the construction of ethnic identity in Indonesia. This article has a modest goal of bringing some aspects of the everyday life of one group of Indonesian Indians to the attention of scholars, and providing a basis for further inquiry on how ethnicity, whether real or imaginary, operates in contemporary Indonesia.

13 Benedict R.O'G Anderson, 'Introduction', in Southeast Asian tribal groups and ethnic minorities: Prospects for the eighties and beyond, ed. Ruth Taswell, Cultural Survival Report 22 (Cambridge, MA: Cultural Survival, 1987), p. 3.

14 See Edward Aspinall, 'Democratization and ethnic politics in Indonesia: Nine theses', Journal of East Asian Studies 11, 2 (2011): 289-319.

15 See, for example: Jacques Bertrand, Nationalism and ethnic conflict in Indonesia (Cambridge: Cambridge University Press, 2004); Richard Chauvel, 'Electoral politics and democratic freedoms in Papua', in Problems of democratisation in Indonesia: Elections, institutions and society, ed. Edward Aspinall and Marcus Mietzner (Singapore: ISEAS, 2010), pp. 307-29; Gerry van Klinken, 'Ethnicity in Indonesia', in Ethnicity in Asia, ed. Colin Mackerras (New York: RoutledgeCurzon, 2003); Chris Wilson, Ethno-religious violence in Indonesia: From soil to God (London: Routledge, 2008).

16 See, for example, Donald E. Willmott, The national status of the Chinese in Indonesia, 1900-1958 (Ithaca, NY: Modern Indonesia Project, Cornell University, 1961); Leo Suryadinata, The Chinese minority in Indonesia: Seven papers (Singapore: Chopmen, 1978); Charles A. Coppel, Indonesian Chinese in crisis (Kuala Lumpur: Oxford University Press, 1983); James Mackie, The Chinese in Indonesia: Five Essays (Honolulu: University of Hawaii Press, 1976); Jemma Purdey, Anti-Chinese violence in Indonesia, 1996-1999 (Honolulu: University of Hawaii Press, 2006); Law and the Chinese in Southeast Asia, ed. Michael B. Hooker (Singapore: ISEAS 2002); Karen Strassler, 'Cosmopolitan visions: Ethnic Chinese and the photographic imagining of Indonesia in the late colonial and early postcolonial periods', Journal of Asian Studies 67, 2 (2008): 395-432; Chang-Yau Hoon, Chinese identity in post-Suharto Indonesia: Culture, politics and media (Portland, OR: Sussex Academic Press, 2008); Filomeno V. Aguilar, 'Citizenship, inheritance, and the indigenizing of "Orang Chinese" in Indonesia', positions: asia critique 9, 3 (2001): 501-33; Ariel Heryanto, 'Ethnic identities and erasure', in Southeast Asian identities: Culture and the politics of representation in Indonesia, Malaysia, Singapore, and Thailand, ed. Joel S. Kahn (Singapore: ISEAS, 1998); Krishna Sen, “'Chinese” Indonesians in national cinema', Inter-Asia Cultural Studies 7, 1 (2006): 171-84; Elizabeth Chandra, 'Blossoming Dahlia: Chinese women novelists in colonial Indonesia', Southeast Asian Studies 4, 3 (2015): 533-64. 


\section{Occupation and foreignness: Dual distinction}

The dual distinction in sinetron production culture based on occupation, on the one hand, and on foreignness, on the other, is rooted in two different historical and cultural experiences. For Hindu Sindhis, the sinetron PH owners and executive producers, who trace their ancestry to South Asia, the institution of caste defines most social relations. Meanwhile, local Indonesians, who classify people into locals and foreigners, follow a social system based on ethnicity, introduced in the archipelago during colonial rule. Despite different histories and cultural contexts, these two views of social hierarchy have merged almost seamlessly to form a rigid social structure in the leading sinetron $\mathrm{PHs}$ in Indonesia.

From the 1990s to the early 2010s the PH personnel were ethnically diverse. Department heads were all from the local Sindhi community. The directors, scriptwriters, and editors were mostly overseas professionals, predominantly from India. Expats usually constituted up to 15 per cent of the staff; the rest were Indonesians, from Jakarta, the centre of mainstream sinetron production, or other parts of the country.

\section{The occupational distinction}

Based on his research on the global Sindhi community, Mark-Anthony Falzon stated that "by and large most Sindhis classify themselves and others as being either "businessmen" or "in service". ${ }^{17}$ There are of course categories that do not quite easily fit into either groupings, such as the professions, but these two remain nevertheless determining. Further, the distinction between bosses and those 'in service' is an hierarchical one because being self-employed is considered superior to being an employee. According to Sindhi bhaibands, businessmen have knowledge, skills, connections and patronage, and thus, power, while those in service are much less competent and privileged. ${ }^{18}$ This distinction is projected into the inner hierarchy of companies headed by Sindhis, where the major dividing line is drawn between 'bosses' and everyone else, Sindhis and non-Sindhis alike. As will be shown below, the wide gap existing between employers and employees is rarely, if ever, crossed. The only way for those 'in service' to move to the category of 'bosses' is to set up their own business. Self-employment is the top priority for those who wish to be a part of the Sindhi community.

The idea that a true Sindhi should eventually become his own boss remained almost unshaken by the social, economic and political changes in India and Indonesia in the late twentieth and early twenty-first centuries. ${ }^{19}$ Despite the fact that the younger generations show a preference for professional careers over family business, by and large the community remains 'synonymous with business'. ${ }^{20}$ After

17 Falzon, Cosmopolitan connections, p. 189.

18 The majority of Indonesian Sindhis are bhaibands (lit., 'brothers'). Although Hindu Sindhis mostly form one caste, known as Lohana, there are still some inner divisions, i.e. the prestigious amils and the lowerclass but wealthy bhaibands. See further Markovits, The global world of Indian merchants, pp. 46-8.

19 In the global Sindhi community business generally remains a male-dominated world. For more on Sindhi gender ideology, see Falzon, Cosmopolitan connections; and Anita Raina Thapan, Sindhi diaspora in Manila, Hong Kong, and Jakarta (Quezon City: Ateneo de Manila University Press, 2002).

20 Falzon, Cosmopolitan connections, p. 89. 
several years of building a professional career, Sindhis usually join the family business or start their own:

My son is back in the family business. But after he graduated he went to work in a bank in Singapore. And I had a lot of my friends asking: he is your only son so why is he not in your family business? I didn't want him to join so we just let him. And later on he joined the family business. So he got into it himself - out of choice. But he works in a completely different way and style. This is what many children do nowadays. They enter the business and they change the way - they do it professionally. ${ }^{21}$

It is obvious that younger Sindhis eventually come back to a more traditional Sindhi way of life. The idea that being 'in service' is only valuable if it is a stepping-stone on the way to becoming a businessman, and thus a respectable member of the highly exclusive and wealthy community of Indonesian Sindhis, continues to prevail.

The distinction between bosses and everyone else is reproduced in the sinetron production business. For the Sindhi producers, there is no big difference between actors or gaffers, directors or dolly pushers. All of them are service providers, no matter how different their roles may be. The services of some industry workers, like sinetron stars, foreign directors and scriptwriters, do imply higher fees and certain distinctions and privileges. But higher salaries do not lift production workers beyond the imaginary line separating bosses from the rest of the industry. The latter are still 'in service'. In other words, from the Sindhi point of view, the major difference is not between upper-class labour, intellectual or creative, and working-class manual labour, but between those who manage themselves and others, and those who are managed.

To some extent, this division between bosses and everyone else is similar to the division between employer and employee fixed by Western copyright law, although I do not believe that the cases are identical. The occupational distinction here is rooted in South Asia's caste system, which structures society in accordance with occupation, inherited rank, privilege and wealth. Unlike the usual distinctions between employer-employee, in which the main difference is economic, i.e. 'an ability to use capital to employ or contract with creative workers', ${ }^{22}$ the distinction between Sindhi bosses and those 'in service' has important social implications as well. For Sindhis being a boss is the main, if not the only, way of getting social recognition and respect from fellow Sindhis, while for example, for employers/copyright holders in the United States there are other equivalent ways of exhibiting a higher status, such as degrees from prestigious universities or the ownership of art collections.

\section{Foreignness}

The second and concurrent distinction that has shaped social relations in the sinetron PHs owned by the Indonesian Indians is also directly related to ethnicity, but in quite a different way. Unlike the distinction based on occupation, in this case the division into locals and foreigners is projected from below and is rooted in

21 Sheeja, Indonesian Sindhi housewife, interview (in English), 22 Feb. 2013.

22 Stahl, 'Privilege and distinction in production worlds', p. 56. 
the relatively recent colonial past of Indonesia. For political and economic reasons, the Dutch colonial rulers classified the population of the Indonesian archipelago into three broad categories: natives, 'Foreign Orientals' and Europeans. While natives (with the exception of local aristocracy) were at the bottom of the social hierarchy, and Europeans at the top, 'Foreign Orientals', mainly Chinese, Indians and Arabs, were somewhere in between. ${ }^{23}$ Unlike the natives, Chinese, Indians and Arabs were given some social, legal and economic privileges, which were, however, not exactly equal to those accorded to the colonial elites. The nationalist governments of Sukarno and Suharto continued to use similar categories for the population: pribumi (natives), WNI keturunan asing (Warga Negara Indonesia keturunan asing; Indonesian citizens of foreign descent), and WNA (Warga Negara Asing; foreign citizens). ${ }^{24}$ The logic behind the distribution of material and symbolic benefits of these categories was largely reversed, however. Pribumi status guaranteed certain economic, political and social privileges, while WNA and WNI keturunan asing were often deprived of basic rights. The pribumi were regarded as asli (authentic) inhabitants of the land, whereas Indonesians of foreign descent were seen as non-asli, or not real Indonesians. ${ }^{25}$ Following the fall of the New Order regime in 1998, President B.J. Habibie abolished the racist pribumi and non-pribumi division by issuing Presidential Instruction 26/1998. A new Citizenship Law (No. 12 of 2006), introduced eight years later, 'stipulated a redefinition of the term "indigenous Indonesian", "pribumi" or "asli", to include all Indonesian citizens who have not assumed foreign citizenship'. ${ }^{26}$ Despite the official eradication of distinctions between the two, the division into 'us' and 'them', or locals and foreigners, has persisted in public discourse. In colloquial language these differences are often expressed as orang kita (lit., 'our people') and orang sana (lit., 'people from there').

For most of my respondents, there was no substantial difference between Indonesians of foreign origins (Chinese, Indians or Arabs) and foreign nationals. The former were almost as foreign as the latter. They were non-Indonesians, or at least not 'real Indonesians':

23 The classification was, in fact, more nuanced and complicated than this. See, for example, Cees Fasseur, 'Cornerstone and stumbling block: Racial classification and the late colonial state in Indonesia', in The late colonial state in Indonesia: Political and economic foundations of the Netherlands Indies, 1880-1942, ed. Robert Cribb (Leiden: KITLV Press, 1994), pp. 31-56; Ariel Heryanto, Identity and pleasure: The politics of Indonesian screen culture (Singapore: NUS Press; Kyoto: Kyoto University Press, 2014), in particular, pp. 133-65.

24 The category of WNI keturunan asing was created with the special purpose of differentiating between peranakan (lit., 'mixed blood', acculturated) and totok (lit., 'pure blood', recent migrants) Chinese. After the People's Republic of China (PRC) extended citizenship to all non-resident Chinese, the Indonesian government forced local Chinese to choose their citizenship and to actively reject PRC citizenship if they wished to retain Indonesian passports. Those who rejected PRC citizenship and pledged their loyalty to the Indonesian state, in accordance with the Citizenship Act of 1958, were classified as WNI. Those who did not fell into the category of WNA, or foreigners. Many Indonesian Chinese saw the regulation as discriminatory, because pribumi did not have to actively declare their Indonesian citizenship. Chang-Yau Hoon, 'Reconceptualising ethnic Chinese identity in post-Suharto Indonesia' (PhD diss., University of Western Australia, Perth, 2007), p. 94.

25 Ibid., p. 4.

26 Ibid., p. 4. 
Although they are WNI [Indonesian citizens] all of them are still thinking about India. Chinese are also the same. They are not Indonesians. It is quite fair to say this ... Their families are there ... When they have money, they always send it to their families there. They don't care about Indonesia. It is only for business. That's it. ${ }^{27}$

This statement provides a clear idea of how those who consider themselves as local Indonesians draw the line that separates them from 'foreigners'.

My interviews showed that Sindhi producers were very much aware of the persistence of this discourse. During my conversation with Raam Punjabi, he pointed out that he was still perceived as a foreigner despite the fact that he was born in Indonesia and had held an Indonesian passport for almost thirty years:

I'm not a foreigner, I'm a citizen by naturalisation. I became Indonesian in 1976. I had to give up my Indian passport. But here people still have different thinking. In America if you have an American passport whether you are of German or Polish origins you are American. But here there is still this pribumi. ${ }^{28}$

In other words, the official abolishing of these categories more than a decade ago did not bring about substantial change. Raam was still not seen as a real Indonesian. Even his children, Karishma and Amrit, Indonesian citizens by birth, were seen as foreigners:

At the end of the day mostly local people see us as Indians but we are not - we are actually Indonesians. It is our bread and butter. We were raised here, we live here. Our daily food is not Indian, it's Indonesian. And still people think we are Indian. But we are actually more Indonesian. ${ }^{29}$

The hierarchy of 'us' and 'them' is not as clear-cut as in the case of the occupational distinction and is easily reversible, however. On the one hand, foreigners are perceived as knowledgeable, skilful, and thus, authoritative. An Indonesian of Sindhi descent vividly depicted an interaction between foreign and local staff in the Sindhiowned PHs, highlighting the higher social and professional status of foreigners:

For Indonesians it's a pride: 'I'm working with a director from abroad. My CV looks good!' So it's a win-win situation. But if director stays here for five years then he loses his charm. But when he first comes it's wow! They [Indonesians] will ask you what films you have made and then you show your profile and then they will say - oh, keren ['cool']. It's fun to see how they [local Indonesians and foreigners] interact. ${ }^{30}$

In the words of another respondent, an expatriate from India, in Indonesia they respect you for being a foreigner. They [local Indonesians] appreciate it.' 31

On the other hand, foreignness is often equated with viciousness, decadence and degradation. For example, the Broadcasting Act of 2002 states that the aim of the broadcasting industry, is, among others, to 'strengthen the ability of people to deter

27 Handi Atmaja, Indonesian producer/director/scriptwriter, interview (in Indonesian), 22 Feb. 2013.

28 Raam Punjabi, Indonesian Sindhi producer, interview (in English), 18 Feb. 2013.

29 Karishma Punjabi, Indonesian Sindhi producer, interview (in English), 18 Feb. 2013.

30 Nagesh, Indonesian Sindhi line producer, interview (in English), 17 Apr. 2013.

31 Amol, Indian national, member of creative team, interview (in English), 11 Mar. 2013. 
[the] bad impact of foreign values'. ${ }^{32}$ During my fieldwork the discussions of bad foreign influence ruining (good) Indonesian culture was one of the favourite topics of sinetron industry workers. In that context, from the local Indonesians' point of view, on the one hand, the foreign (Indian) ethnicity of Sindhis justified their position at the top of the social hierarchy. Moreover, the Sindhis' wealth combined with their linguistic skills (proficiency in English and/or Sindhi/Hindi) added legitimacy to their claims of superiority and control. Similarly, overseas professionals, directors and scriptwriters, were ascribed a higher social status. On the other hand, the foreignness of producers and expats was potentially their weak spot.

Taken together, both these distinct views on social relations, rooted in different historical experiences and modes of existence, formed a rigid social hierarchy, where ethnic imagery played a key role. Imposed from above in the form of occupational distinction, this hierarchy was passively supported from below by the complex understanding of foreignness. As Budi, one of my respondents, an experienced sinetron scriptwriter, put it in response to my question about whether the production staff still perceived their producers as Indians:

We still see them as Indians even though they speak Indonesian. Because basically, at the end of the day, they are still the bosses. They are the 'suits'; we are the workers. There is always that gap. ${ }^{33}$

Budi's account makes it clear that there are two, almost coalescing categories of distinction, separating those of foreign origin/foreigners/bosses from Indonesians/workers.

\section{Production practices}

The social relations structured by the ethnocultural frameworks of Sindhis and local Indonesians are manifested in the various sinetron-making practices. The actual filming of a series is one of the main sites where power relations in the PHs become particularly visible, and importantly, observable by outsiders. Unlike production meetings or creative team briefings, sets are the most accessible sites for researchers of production culture.

Here, the divide between bosses and those 'in service' is transformed into a division into orang kantor ('office people') and orang lapangan ('field people') - the set being the place for those 'in service'. Bosses, the owners/executive producers, rarely attend shooting sites; if they do appear, it is usually in a capacity other than as bosses. For example, in April 2012 Manoj Punjabi, the owner/producer of MD Entertainment (henceforth MD), came to the set to play a small part (cameo) in a sinetron. In an interview published online, he was quoted as saying: 'This is the first time for me to become an actor. New experience. From the "office staff" I became a "field person".'34 This account is significant for two reasons. First, Manoj found it

32 Undang-Undang Republik Indonesia Nomor 32 Tahun 2002 tentang Penyiaran [The Broadcasting Act of the Republic of Indonesia No. 32, 2002] (Jakarta: Indonesian Broadcasting Commission, 2013), p. 40.

33 Budi Susanto, Indonesian sinetron scriptwriter, interview (in English), 1 Mar. 2013.

34 '(In Prod) Tendangan si Madun the movie' [(In Production)] The movie Tendangan si Madun], Yusuf Mahardika and Louise Anastasya, Lautan Indonesia forum entry, posted 29 Apr. 2012, http:// www.lautanindonesia.com/forum/index.php?topic=112952.0;wap (last accessed 12 Jan. 2015). 
necessary to draw attention to his temporary change of status - from the 'office' to the 'field'. The emphasis on this aspect of his experience in a brief interview suggests that this division plays a significant role in the social hierarchy. Second, Manoj's words clarify that actors belong to the category of 'field people', those below the line. In comparison, in PHs owned by pribumi producers, the gap between office and field people barely exists, and producers/PH owners often attend the shooting sites, seeing themselves (and being seen) as part of the crew.

Sindhi bosses convey their messages to the field practitioners through line producers and chief directors. Line producers are, as a rule, from the Jakartan Sindhi community. Chief directors, in charge of directing pilot episodes and supervising several shooting teams led by assistant directors, are expats from India. ${ }^{35}$ The assignment of the middlemen positions to Indonesians of foreign descent and foreigners is deployed by Indonesian Sindhi bosses strategically: it helps in maintaining social distance and imposing more authority on subordinates. The foreignness of line producers and directors adds weight and value to their instructions, commands and demands. I did sense some dissatisfaction with the existing state of affairs in comments like 'our people [orang kita] are never given [a chance] to direct pilot episodes' ${ }^{36}$ In general, however, line producers, Indonesian Sindhis, and foreign directors, Indian nationals, are highly respected and obeyed by the crew - both as professionals and as foreigners.

Besides that, the hierarchy based on occupational status and foreignness manifests itself through the working conditions on the set. When analysing Bollywood shooting practices, Tejaswini Ganti observed the 'stark contrast between stars and everyone else around them, especially the way stars are accorded a great deal more basic comforts than the rest of the cast and crew'. ${ }^{37}$ On the sets of $\mathrm{MD}$, MultiVision Plus (MVP) and other PHs owned by the local Sindhis, it is only foreigners and sinetron stars who are allocated certain privileges. ${ }^{38}$ The working conditions provided for the foreigners and stars, and the rest of the cast and crew do not differ greatly. The former would at best be provided with more serves of coffee, a separate restroom, a chair to sit on during the long hours of shooting, and in some rare cases, a bed to lie down; while the rest of the crew would take a nap on the ground and manage through a whole day's shoot with occasional energy drinks.

There is also a significant difference in the way food is served for the privileged versus the rest of the production workers. One example from an MVP set will

35 Sinetron episodes are shot everyday for broadcast the next day. This method of production, known as stripping, requires having several production teams working on the same episode during a shoot, so usually the crew is divided into three or four teams, each working under the direct supervision of assistant directors, who then report to the chief director.

36 Tedi Lukmanto, Indonesian sinetron director, interview (in Indonesian), 12 Feb. 2013.

37 Ganti, Producing Bollywood, p. 205. Ganti underlines that there is a significant difference between 'stars' and all other actors because 'not all actors are categorized as "stars" by the Hindi film industry, which has a particular taxonomy of actors related to narrative presence, commercial success, career trajectory, and tenure within the industry', ibid., p. 208.

38 Similar to their Hindi counterparts, in the Indonesian industry only a few are 'stars'. This status is measured monetarily and mostly linked to commercial success and 'people's choice' awards, such as the Panasonic Gobel Awards. There are only five to ten sinetron actors with 'star' status. A 'star' can earn 20,000,000 rupiah (roughly US\$2,000) per episode while a lead actor usually earns no more than 3,000,000 rupiah (US\$300). 
illustrate my point. During one shoot I attended, lunch was offered in two different ways. For the crew and cast the food was distributed in plastic containers right on the set. At the same time, an errand boy prepared a separate table in an airconditioned house near the site. Only a chosen few were invited to the table: the executive producer (Indonesian Indian), the line producer (Indonesian Indian), the director (Indian national), the finance director (Indian national) and me (Russian-Australian researcher). ${ }^{39}$ Everyone was offered exactly the same food (fried rice, chicken and some vegetables). But the way they had their meal - on the set, under the burning sun, out of plastic containers, or being served in an airconditioned room, with porcelain and silverware table settings - clearly reinforced the social distinction. Actors, including the lead actors, none of whom were sinetron stars, were not invited to join the meal served in the house. Only stars are entitled to certain privileges. In contrast, when I visited the sets where the crew consisted only of pribumi, there was no differentiation between producers, directors, actors (including stars) and the rest of the crew at mealtime. Everyone ate together.

Office celebrations were another practice where hierarchy built on occupational distinction and foreignness becomes visible. From an anthropological point of view, office celebrations can be seen as 'production rituals', aimed at maintaining coherence and stability within a particular production culture. Diwali, the main Indian festival, is celebrated in all PHs owned by the Indonesian Indians. In fact, Diwali is the only Indian festive event that Sindhi bosses celebrate with their employees. MD provided a detailed description of the Diwali celebration held in its office in 2014: when 'authentic vegetarian Indian food' was served, all the MD staff 'neatly lined up' for food 'without regard to their position and status' ${ }^{40}$ The emphasis on the absence of distinction during the festival underlines its usual significance in production life.

The fortieth birthday celebrations for Manoj Punjabi, head of MD, offers another example of how the Sindhi bosses draw the line when it is time for more substantial 'gift giving' than food sharing. To celebrate his birthday, Manoj had invited his idol, Bollywood mega star, Shah Rukh Khan, to perform in Jakarta. The invitations for the gala show were distributed only to the expatriate (Indian) workers, heads of various departments (Indonesian Sindhis) and sinetron stars, not the whole MD staff (around 200 people). A similar distinction was made when MD organised a cruise after a very successful season of one of the sinetron titles. Only Indian nationals and Indonesians of Indian descent, as well as stars, were invited to join this celebratory tour. In sum, when there is an occasion to share some material and symbolic benefits of production, the distinction is mostly made on the criteria of foreignness and occupation. ${ }^{41}$

39 As mentioned, the executive producers rarely visit the sinetron sets. Amrit, Raam Punjabi's son who had just been appointed the executive producer of the series, wanted to familiarise himself with the set. 40 See 'Berita [News]' MD, MD Entertainment, http://www.mdentertainment.co/berita/index/7 (last accessed 14 Jan. 2015).

41 All other Indonesian Indian-owned PHs (MVP, Soraya Intercine, Rapi and Mega Kreasi) have a similar approach to office celebrations and distribution of material benefits to their cast and crew. Most of my examples are from MD because at the time of my fieldwork (2013) MD was the most open to outside observers, and produced a substantial amount of self-reflective materials, such as brochures, promo materials and updates on their corporate website, whereas other PHs usually do not disclose their internal practices for public consumption. 


\section{Contestation over power (authorship)}

I have argued that the two distinct cultural frameworks within Indonesian Indian PHs form quite a rigid social structure. Yet it is always challenged from within as well as from the outside. One of the main factors that often leads to power redistribution in media production is contestation over authorship. Although television programmes are a result of teamwork, not individual endeavour, authorship is neither shared equally among the production workers, nor follows naturally from particular skills and tasks. ${ }^{42}$ Authorship is an exercise in power. Those who have power are able to and, as a rule, do claim a fair bit of authorship, and even proprietary rights to the product. At the same time, those who might not have much control over production but who feel they have made a substantial contribution to the product, can make a strong case for gaining decision-making power in the production. In other words, authorship is never fixed; it is subject to constant negotiation, even struggle, among individuals and/or various groups involved in the production process: as Jonathan Gray and Derek Johnson remark, 'authorship is ... about control, power, and the management of meaning and of people as much as it is about creativity and innovation'. ${ }^{43}$

Claims for authorship can be expressed in different ways, and are themselves products of specific discursive practices. For example, they can be voiced through the rhetoric of creativity and responsibility, ${ }^{44}$ or formulated in quite concrete and specific terms such as 'aesthetic status metaphors', 'idea-theft', 'writing by committee' and 'mentoring'. ${ }^{45}$ In Indonesian Indian-owned PHs the claims for authorship, or ownership, of a product is often centred on the idea of indigeneity, which is directly linked to ethnic imagery. In other words, the ethnocultural identity of participants of the production process and certain associations that go along with it play an important role both in establishing a rigid social structure and in constantly challenging it.

\section{Indigeneity}

When asserting authorship over a particular sinetron, its workers - those below the imaginary line separating the privileged and the rest - often see pribumi-ness as the main bargaining chip in their struggle over authorship of the product of their labour. A recurring theme in my interviews with local directors, DOPs, scriptwriters and others was the rhetoric of indigeneity as a value in sinetron production. For example, when Budi Sutanto shared his experiences as head of MVP's creative department during the late 1990s to the early 2000s, he recalled the following:

I went to India seven times - to choose writers mostly. At that time, we needed more stories and we relied on regular Indian writers. Mr Raam would go to India, I would go with him ... I was interviewing writers and since I knew more or less what Pak Raam

42 See, for example, Dornfeld, Producing public television; Stahl, 'Privilege and distinction in production worlds'; Jonathan Gray and Derek Johnson, Companion to media authorship (Chichester: Wiley-Blackwell, 2013).

43 Gray and Johnson, Companion to media authorship, p. 4.

44 Stahl, 'Privilege and distinction in production worlds', p. 59.

45 Caldwell, Production culture, p. 201. 
needed and since I am an Indonesian, usually I could guess ... whether there are new subjects not written in Indonesia. It was very interesting actually. ${ }^{46}$

According to Budi, it is not his professionalism as a scriptwriter that made him an asset for the company, but his Indonesianness. The fact that Budi does not use the word 'local' or does not specify that he is a local Indonesian, makes the meaning of what he is saying even stronger. In Budi's view, Raam Punjabi is not an Indonesian at all, despite the fact that he, like Budi, was born and brought up in Indonesia. And because of his 'foreign origin', Raam is just unable to grasp the essence of Indonesianness, a skill Budi possesses by default, as ‘a true Indonesian'.

Yuliana, a scriptwriter with extensive experience of working for various PHs, including those owned by the Indonesian Indians, applied a similar logic when she discussed the Sindhi producers' inability to make comedies with local ethnic flavour:

\section{Yuliana:}

It seems like if it is Betawi [humour] they [producers of Indian descent] can't do it. Because of their culture. Even though they are here for a long time they still can't see it [Betawi culture]. ${ }^{47}$

\section{Author:}

How do you prepare yourself for writing a local comedy? Do you spend time at the Betawi village or what do you do?

\section{Yuliana:}

Usually if we want to make a local film at most we will go and check the location, how it looks like, who these Betawi people are. So we will just go there, see the settings. And after that we'll write the story straight away. It's not that difficult after all. ${ }^{48}$

Significantly, Yuliana herself is not Betawi. She was born and raised in Sulawesi. But in Yuliana's view, her non-Betawiness does not impede her writing about Betawi people. She and other local Indonesian colleagues claim that they can easily grasp the essence of Betawi culture by simply visiting a location, a possibility that is closed to Indonesians of Indian descent because of their foreignness. Likewise, in his research on the adaptation of foreign products to the Indonesian market, Philip Kitley quoted a young director/producer from Sumatra, saying that adapting programmes for local audiences is an art, and can be done properly only by the local Indonesian people, not foreigners, in which category they included both foreign nationals and Indonesians of foreign descent. ${ }^{49}$

While sinetron production workers appeal to their indigeneity, the bosses ground their (counter-) claims for authorship on the rhetoric of genes. Sindhi producers

46 Emphasis added; Budi Susanto, interview, 1 Mar. 2013.

47 Betawi are the native inhabitants of Jakarta, and known to have a particular sense of humour, which has been popularised through mainstream television. See Klarijn Loven, Watching Si Doel: Television, language, and cultural identity in contemporary Indonesia (Leiden: KITLV Press, 2008).

48 Yuliana Chandra, Indonesian scriptwriter, interview (in Indonesian), 17 Apr. 2013.

49 Philip Kitley, 'Closing the creativity gap: Renting intellectual capital in the name of local content; Indonesia in the global television format business', in Television across Asia: Television industries, programme formats and globalization, ed. Albert Moran (London: RoutledgeCurzon, 2004), p. 148. 
assert that their ability to make films for television or the wide screen is part of their DNA:

Indians have the culture of making movies. I feel it's in our blood. I guess you [either] have it or not. There are so many players in this industry - around 3,000 but I can't mention more than 15 and then the ones who are surviving are less than 10 . The real performers are less than 5, out of which 4 are owned by Indians and 1 is owned by a Chinese ... When Indians in India go for a movie they still believe in the first day show ... I will dress up to suit the movie. Indians are like that. So I think DNA somehow passes through us. We have strong roots when movies are concerned. ${ }^{50}$

Like Budi, Manoj attributes his success in the industry primarily to his genetic make-up. Film culture is something one is born with or into, not something to be acquired through learning and practice. One can become skilful and experienced in production but education and hard work has its limits, and cannot guarantee success.

The idea of indigeneity as one of the cornerstones of the production process has its roots in the Film Nasional discourse, constructed by nationalist ideologues from the early days of Indonesian independence. Film Nasional was a state ideology succinctly defined by Thomas Barker as 'pribumi, idealist and nationalist'. ${ }^{51}$ The ideologues and practitioners of national cinema evaluated films based on their potential to instil nationalistic ideas in the audience. In this regard the production process, and more precisely the filmmakers' ethnocultural identity, was as important for national cinema as the stories told, and the faces shown on screen. ${ }^{52}$ According to the ideologists of Film Nasional, only pribumi, or indigenous Indonesians, could produce quality (read nationalistic) films. Those of foreign origin were not able to do so by virtue of their race'. ${ }^{53}$ When commercial television was sanctioned in Indonesia in the late 1980s, the film industry was stagnant and many film professionals became involved in sinetron production. Although commercial television operated on very different principles, according to which a good programme meant a commercially successful, not necessarily ideologically correct programme, the nationalist views of film industry workers continued to circulate within the production world.

The rhetoric of indigeneity in the sinetron industry as tracked during this study has not resulted in any substantial redistribution of power within the Sindhi-owned PHs. In this production culture, which allocated control based on occupational distinction and foreignness (foreign ethnicity and nationality), strongly associated with knowledge and skilfulness, indigeneity was not worth much. It is neither a professional skill nor a rare commodity.

50 Manoj Punjabi, Indonesian Sindhi PH owner/executive producer, interview, 3 Apr. 2013.

51 Thomas A. Barker, 'A cultural economy of the contemporary Indonesian film industry' ( $\mathrm{PhD}$ diss., National University of Singapore, 2011), p. 39.

52 See Barker, 'A cultural economy'; and Saraswati Sunindyo, 'Gender discourse on television', in Culture and society in New Order Indonesia, ed. Virginia M. Hooker (Kuala Lumpur: Oxford University Press, 1993), pp. 134-48.

53 Barker, 'A cultural economy', p. 39. There were several exceptions, e.g. Teguh Karya, one of the most prominent New Order-era film directors, who produced highly patriotic and nationalist films, was of Chinese descent. See Sen, “Chinese” Indonesians'. 
At the same time, since the mid-2000s there has been a tendency towards a revival of the discourse of national culture as the primary objective of television. This shift has been promoted by the Komisi Penyiaran Indonesia (KPI; Indonesian Broadcasting Commission). Many industry practitioners oppose the KPI as they see it as a revival of New Order-style media censorship and control. The KPI's active use of the concept of Budaya Indonesia (Indonesian culture) in its reports and warnings to television channels - without giving a precise definition of what this culture consists of - creates an environment where indigeneity can be seen as a strong claim for the ownership of the product.

\section{Credit titles}

Besides the rhetoric, ethnic imagery stands behind a very practical tool for regulating the allocation of authorship in the production process, i.e. the organisation of credit titles. In Barry Dornfeld's definition credit titles

represent the division of responsibilities in typographical distinctions, assign an order of importance to job categories, and ascribe to a single producer/directors the authorship of the shows for which they had primary responsibility. ${ }^{54}$

In the case of PHs owned by the Sindhis the ethnic factor does have an impact on one aspect of the credit titles - the practice of inclusion/exclusion of certain names to/from sinetron credit titles.

There are two overlapping categories of industry workers whose names are regularly excluded from the credit titles of soap operas made in Sindhi-owned PHs: members of the so-called creative team and expatriates. I should say that omitting the names of the writers' team is a common practice in all sinetron PHs in Indonesia, not only in those owned by the Sindhis. ${ }^{55}$ The screenwriters' contributions are mostly often summed up by a set expression: 'story by [PH's name] creative team'. Meanwhile, the exclusion of expats' names occurs only in the PHs owned by the Indonesian Indians. Consider the case of Rajesh, one of the Indian directors who worked for both Sindhi and non-Sindhi-owned PHs during various periods of his career in Indonesia. When working for SinemArt, a PH owned by a non-Sindhi, Rajesh was always mentioned in the credits. When he moved to MD, his name vanished and was replaced by the name of one of his local Indonesian assistants. There is, however, an important nuance - the names of expat workers are mentioned in the first, or pilot, episodes of dramas, but are omitted in all subsequent ones. When I asked my expatriate respondents to comment on this practice, they usually gave me the following answer: 'We come here [to Indonesia] for money, not names.' They would also mention that producers were constantly worried that their creative labour would be 'stolen' by the rival PHs. The expatriates themselves found this reason quite ridiculous, as sinetron production in Indonesia is a small world and usually people know each other anyway.

54 Dornfeld, Producing public television, p. 73.

55 See 'Jangan remehkan credit title tim penulis skenario' [Do not belittle writers' team in the credit titles], Detik Hot, 16 Jan. 2014. http://hot.detik.com/read/2014/01/06/172255/2459637/ 1059/jangan-remehkan-credit-title-tim-penulis-skenario (last accessed 14 Sept. 2014). 
Along with exclusion, there is also a practice of including the names of people who have minimal or even no relation to the project:

Indian producers are bold enough to pay only for the names. They need only names. There were several cases - the names appeared in the credits but I was not sure whether people actually worked [on that programme]. Maybe only on the pilot episodes. I was asked three times - my name was mentioned in the credits but I didn't work. Financially it was beneficial but from business side I lost. There was no guarantee it was a good programme. ${ }^{56}$

For producers manipulating the credits is a rather costly practice: expatriate workers require monetary compensation for the loss of their 'career capital'. And local Indonesian directors/scriptwriters demand to be financially covered for the risk of damaging their professional reputations in case sinetron produced under their names do not meet certain standards of quality (usually set by the professionals themselves). ${ }^{57}$

Why do producers want to incur additional expenses to juggle the names in the credits? I would argue that in one way or another ethnic imagery and the associated perceptions of foreignness and indigeneity are behind this complex organisation and reorganisation of sinetron credits. To begin with, pilot episodes target a specific audience of TV channel management that sees foreign crew as a guarantee of quality for drama series, and local Indonesian crew as a key to successful comedies. Thus, to sell pilots to TV channels Sindhi producers will keep the names of their expatriate workers in the credits for dramas and pay extra to get the names of top local directors/writers for sitcoms. After the pilots are sold, producers rearrange the credits by dropping the names used for the initial marketing phase.

The exclusion of foreigners from the credit titles could, in fact, be a strategy of the Indonesian Indian producers to protect themselves from possible ownership claims by expats who usually have a rather developed 'authorial self-understanding' grounded on professional skills, creative contribution and responsibility. ${ }^{58}$ According to the Indonesian Copyright Law of 2002 (still in force during my fieldwork in 2013), an author is defined as 'the person whose name is mentioned in a Work or published as the Author of a Work'. ${ }^{59}$ Thus, by omitting the names of the contributors in the credits, the producers of Indian descent could be reducing the risk of legal disputes over proprietary rights. They are protecting their status as the sole copyright holders.

But the reasons for dropping the names of expatriate workers go beyond immediate commercial interests. My respondents, both Indonesians and expats, often linked the exclusion of overseas labour from sinetron credits with fear of a xenophobic backlash by the public: 'if there were too many foreign names in the credit titles there

56 Handi Atmaja, Indonesian producer/director/scriptwriter, interview (in Indonesian), 22 Feb. 2013. 57 Many Indonesian media practitioners mentioned to me that they had, in their own words, 'developed an idiosyncrasy' towards rules and standards set for media production during the militarist New Order regime. The industry avoided establishing a written set of standards until the early 2010s. Most often, practitioners rely on their own ideas about labour and product quality, acquired through education and/or professional experience.

58 Stahl, 'Privilege and distinction in production worlds', p. 59.

59 Undang-Undang Republik Indonesia Nomor 19 Tahun 2002 Tentang Hak Cipta, Bab I, Pasal 5(1)b [Law of the Republic of Indonesia No. 19 Regarding Copyright, 2002 Part Two, Article 5(1)b]. A new Copyright Law came into force in 2014. 
would be protests in front of our office'.$^{60}$ This statement is important as there is a certain logic at work here. When non-Sindhi PHs hire Indian expatriates they do not feel the need to erase their names from the titles. So it is not the foreign names as such that is an issue, nor even the number of expatriates working on a particular sinetron production that could provoke negative reactions. It is the work of imagination that makes this instinctive linking and equation between Indonesians of Indian descent with Indians from overseas. It is the connection made between local Indians and Indian nationals, or local Chinese and PRC citizens, that can raise suspicion and distrust.

Indonesia's complicated immigration and labour laws restricting the employment of foreigners in the entertainment sector were rarely mentioned by my respondents, but were surely an issue. Again, although it is not only Indonesians of foreign descent who have a record of hiring labour from abroad without following due procedure, the entrepreneurs of foreign descent often become the main targets of accusations of migration and labour law infringements. Several such cases were brought to public attention, especially between the 1990 s and the mid-2000s. ${ }^{61}$ Importantly, during such cases the media usually focused not so much on the fact of non-compliance with the laws and regulations, but on the alleged infiltration of Indonesian culture with foreign cultural elements. Although such critiques in the media were mostly dropped in the late 2000s, PH bosses continue to exercise extra caution to avoid the unnecessary attention of immigration officers as well as journalists. In one way or another, the rather expensive manipulation of credit titles is linked to the ethnicity of producers as well as other participants of the sinetron production process. In other words, ethnicity, understood as foreign or local, played a distinctive role, being simultaneously an asset and a risk factor.

\section{Conclusion}

This discussion has offered an account of the commercial television production culture in Indonesia during the first two decades of the industry's establishment (early 1990s to 2013), with a focus on social relationships within the leading PHs. I have argued that the social hierarchy formed in commercial sinetron production was largely the result of Sindhi perceptions of occupation as the main category of social classification. These views can be traced back to the caste system of South Asia. The perceptions of Sindhis merged well with the ideas of other Indonesians about social hierarchy based on ethnic division, a legacy of the colonial past and postrevolutionary regimes. The rigid social structure shaped by distinct historical experiences helped maintain the operation of PHs during a period of political, economic and social instability - the decline and fall of the New Order regime and transition to democracy, as well as the rapid development of the national television industry.

Ethnic imagery also plays a role in challenging this hierarchy. Contestation over authorship in PHs was often built on the idea of the perceived superiority of one

60 Prashant, Indian national, creative team member, interview, 7 Mar. 2013.

61 For example, see Coen Husain Pontoh, 'Tak ada film, Raam pun jadi' [Raam would be there even without cinema], Pantau 2, 19, 5 Nov. 2001, pp. 44-9, http://pantau.or.id/?/=d/72 (accessed 5 Jan. 2017); and Kitley, 'Closing the creativity gap', for examples of media attacks on Indonesian producers of Indian and Chinese descent. 
ethnicity over another. The rhetoric of indigeneity, a remnant of New Order ideology, continued to circulate among commercial television industry workers. Moreover, foreignness, closely related to ethnicity and colonial imagery, retained its ambivalent status of might and weakness. My analysis of social relations, formed in a rather specific environment of the television industry, has shown that despite sweeping political and legal changes (the abolishment of the pribumi/non-pribumi distinction), and the new economy, social relations and everyday practices continue to be defined by the old ethnic categories.

The focus on the Indonesians of Indian descent, more precisely on the Sindhis, and their position in Indonesian society, contributes to the scholarship on the politics of ethnicity in Indonesia. A comparison between the experiences of Indonesian Indians and the much more extensively studied Indonesian Chinese may shed light on the complexities of past and present ethnic politics.

This case study of the Indonesian soap opera production culture supports Ganti's argument that 'the commercial nature of a media institution does not necessarily render its hierarchy, organisation or working style transparent or universal'.62 Commercial industries are as much the products of capitalism as they are the products of particular cultures with distinct operational logic and dynamics. While a macro analysis of cultural economy provides vital clues on how media industries operate globally and nationally, cultural analysis, supported by ethnographic data, brings to the surface the nuances of everyday workplace practices, which often play a decisive role in shaping power relations in local settings. 